\begin{abstract}
Iranica
Abstracta Iranica Revue bibliographique pour le domaine irano-aryen

Volume 34-35-36 | 2017

Comptes rendus des publications de 2011-2013
\end{abstract}

\title{
Christian Lange, Karl Pinggéra (Hrsg.). Die altorientalischen Kirchen. Glaube und Geschichte
}

Florence Jullien

\section{(2) OpenEdition}

Journals

Édition électronique

URL : http://journals.openedition.org/abstractairanica/41300

DOI : 10.4000/abstractairanica.41300

ISSN : 1961-960X

Éditeur :

CNRS (UMR 7528 Mondes iraniens et indiens), Éditions de l'IFRI

Référence électronique

Florence Jullien, « Christian Lange, Karl Pinggéra (Hrsg.). Die altorientalischen Kirchen. Glaube und Geschichte », Abstracta Iranica [En ligne], Volume 34-35-36 | 2017, document 7, mis en ligne le 15 juillet 2016, consulté le 01 octobre 2020. URL : http://journals.openedition.org/abstractairanica/41300 ; DOI : https://doi.org/10.4000/abstractairanica.41300

Ce document a été généré automatiquement le 1 octobre 2020.

Tous droits réservés 


\section{Christian Lange, Karl Pinggéra (Hrsg.). Die altorientalischen Kirchen. Glaube und Geschichte}

Florence Jullien

\section{RÉFÉRENCE}

Christian Lange, Karl Pinggéra (Hrsg.). Die altorientalischen Kirchen. Glaube und Geschichte. Darmstadt, Wissenschaftliche Buchgesellschaft, 2010, 178 p.

1 Cet ouvrage est une présentation générale des principales Églises de l'Orient, leur formation, leur théologie et leurs traditions. L'Église syro-orientale (des “Assyriens") et l'Église syro-orthodoxe sont présentées (K. Pinggéra), ainsi que leurs liturgies et leurs spiritualités respectives (E. Renhart), avec les tentatives de rapprochements œcuméniques (D. W. Winkler).

\section{AUTEURS}

FLORENCE JULLIEN

CNRS, Mondes iranien et indien, Paris 